\title{
9. Indigenous Water Management: Priorities for the next five years
}

\author{
Sue Jackson
}

\section{Introduction}

Indigenous systems of resource management coexist alongside and interact with the relatively recently introduced and rapidly transforming institutional systems of State land and water management. These latter systems encompass a mix of regulatory and market-based allocation mechanisms, incorporate scientific methods of resource assessment and management, and increasingly aspire to achieve transparency in water planning procedures, including opportunities for public participation in water management decisions. Much of the impetus for reform comes from the 2004 National Water Initiative (NWI), which for the first time in Australian water policy history explicitly recognised Indigenous rights and interests in water. Parties to the NWI have agreed that water-access entitlements and planning frameworks should recognise Indigenous needs (Jackson and Altman 2009).

A further impetus for reform of water management comes from the Water Act 2007 (Cwlth), which requires that the Murray-Darling Basin Authority (MDBA) prepare a Basin Plan to set enforceable limits on the quantity of water that can be extracted from the Basin's ground and surface water resources. In fulfilling its obligations to assess the social and economic impacts of the Basin Plan, the MDBA will have regard for the social, cultural, Indigenous and other public benefit issues. According to Section 22(1) of the Act, the Basin Plan must contain a description of the water resources and the uses to which those resources are put, including by Indigenous people. The significance of Indigenous interests is also acknowledged in the legislative requirement for Indigenous representation on the Basin Community Committee and the establishment of an Indigenous Water Sub-Committee. Consideration of Indigenous interests is one of many plan objectives alongside requirements to implement international agreements, conserve Ramsar Convention sites and meet the water needs of ecological assets. One of the most influential international agreements is the Biodiversity Convention - one that obliges signatories to involve Indigenous people in biodiversity conservation and recognise their distinct values and knowledge systems. There are also international human and Indigenous rights instruments to which Australia is a signatory, including the UN Declaration on the Rights of Indigenous Peoples (United Nations 2008). 
In January 2010, the CSIRO was engaged by the MDBA to undertake a scoping study of the impacts of changes in water availability on Indigenous communities of the Murray-Darling Basin (MDB). The MDBA requested a synthesis of current knowledge of Indigenous cultural, social and economic values of water and a descriptive characterisation of the potential impact of changes in water availability on Indigenous people. The report was to complement other socioeconomic assessments undertaken in early 2010 to optimise the outcomes of the Basin Plan. The study involved consultation with Indigenous groups, a review of the social science, legal and policy literature, and three case studies selected from across the MDB to illustrate the range of water-management issues facing Indigenous people and to describe water-management entitlements and activities undertaken by Indigenous organisations (Jackson et al. 2010). ${ }^{1}$

The scoping study sought to identify the most significant potential impacts arising from the introduction of the Basin Plan - those that would make the greatest difference to water availability decisions or require mitigation. The Plan could have a major impact on regional communities, particularly those groups reliant on irrigation water, through a reduction in consumptive water and by an increase in environmental water allocations. Communities, including Indigenous groups, might also be affected by the way in which the Plan is developed, the consultative approach taken and the degree to which governments respond to their concerns during plan implementation and continuing evaluation.

Time constraints limited the extent to which Indigenous participation could be built into the project design; nonetheless, the research team drew on Indigenous input and expertise at key points in the study. Indigenous representatives expressed a general desire for involvement in the preliminary study, viewing it as an opportunity to contribute to the Basin Plan, although it was realised that the scope and time frames set by the Plan schedule were unrealistic for a comprehensive study. Anxiety over future reductions in access to water and the difficulty of integrating Indigenous knowledge into water-planning processes were seen as critically important and cause for concern. ${ }^{2}$

The CSIRO study noted that there are many areas in which insufficient knowledge and paucity of data hamper efforts to measure specific socio-economic impacts of changes in water availability and to mitigate negative impacts or enhance positive impacts arising from the Basin Plan. Hence, a strong focus is given in the study's recommendations to improving the knowledge base, acting in a

\footnotetext{
1 The Nari Nari (Hay) and Ngemba (Brewarrina) cases describe two Aboriginal groups' efforts to access water under New South Wales' Water Sharing Plans and using the Indigenous Protected Areas model. The third case study, with the Yorta Yorta in Barmah-Millewa Forest, revealed the complexity of interrelated environmental planning frameworks and co-management agreements that affect the Yorta Yorta's engagement in water management in a cross-border Living Murray Icon Site. The full account of all three case studies can be found in the main report (Jackson et al 2010; <www.csiro.au/science/mdb/science >).

2 All concerns expressed to the project team during the study are reported in Jackson et al. (2010: section 3).
} 
precautionary way, and advancing the scientific determination and evaluation of Indigenous water requirements. This effort should be given maximum priority during the next two to three years in order to prepare the MDBA and Indigenous communities to make more substantial advances for the second Basin Plan than might be achieved by the first, given the lack of evidence to inform policy and water allocation decisions. More intensive empirical research should integrate with other economic, social and hydrological modelling studies to provide a more rigorous assessment of impacts from changes to water availability across numerous social, cultual and economic dimensions and in all basin State jurisdictions.

This chapter first — very briefly — outlines the context and key features relevant to Indigenous water rights and interests and summarises the key watermanagement concerns articulated by Indigenous people. The next section outlines the potential socio-economic impacts that could occur with a reduction in water availability brought about by the introduction of sustainable diversion limits (SDLs). The CSIRO report made a number of recommendations to the MDBA. These are reframed in the final section as four potential priority actions for the next five years of basin management.

\section{Indigenous People within the Murray-Darling Basin}

In 2006 there were approximately 70000 Indigenous people representing 3.5 per cent of the total basin population and about 15 per cent of the national Indigenous population (Taylor and Biddle 2004). There are clear differences in population distribution between the Indigenous and non-Indigenous population: Indigenous people are far less likely to reside in large centres and instead to reside in smaller settlements across the Basin. There are 35 discrete Indigenous communities. The largest share of the Basin's Indigenous population is resident within New South Wales (40 per cent), followed by Victoria (29 per cent) (Taylor and Biddle 2004). The Basin's Indigenous population has grown rapidly in recent years and this trend looks set to continue, with implications for the region's settlement pattern.

Indigenous people in the MDB have distinctly different demographic and socio-economic characteristics from the rest of the population. Compared with their non-Indigenous counterparts, Indigenous people have a much younger age profile and tend to have higher levels of disadvantage, with lower employment rates and income status (Taylor and Biddle 2004). ${ }^{3}$ While Indigenous people are commonly employed in the government, health and service sectors, they are

3 For example, only 1.6 per cent of gross personal income accruing to adult residents in the Basin in 2001 went to Indigenous people despite the fact they represented 2.9 per cent of the adult population up to the age of sixty-five (Taylor and Biddle 2004). 
less often employed in the two major industries in the Basin (agriculture and retailing) and seldom found in professional or management positions. Lack of data constrains the picture of their involvement in customary practices such as hunting, fishing and looking after sacred sites.

Across the MDB, Indigenous people use land and water resources in a variety of interrelated ways, including for subsistence use of wild resources, recreation and cultural practices. A range of social and cultural benefits is derived from these uses and interactions. Indigenous people also use water for economic purposes to support customary lifestyles and participate in water-based commercial activity. Participation in water management links many of these water uses; however, it also gives expression to other forms of Indigenous attachment to country, not least being the responsibility under Indigenous customary law to undertake management activities. It is this responsibility that forms the basis of the contemporary assertion of rights to be engaged and involved at all levels of river management and governance (Behrendt and Thompson 2004; Morgan et al. 2004).

According to a number of sources, changes to the region's river systems have eroded its capacity to meet the needs of Indigenous people (Morgan et al. 2004; Ward 2009). The literature contains many accounts of detrimental socioeconomic impacts arising from overdevelopment of the region's water resources and associated environmental impacts (for example, river regulation, seasonal changes to flows, salinity problems and land-use change) (Forward NRM and Arilla-Aboriginal Training and Development 2003; Weir 2009). Indigenous people raise the negative psycho-social effects of loss of control and inability to holistically manage their customary estates, to exercise custodial authority and to prevent further ecological degradation. The Murray Lower Darling River Indigenous Nations (MLDRIN) has also criticised the research and management community for failing to identify Indigenous values in studies of basin ecosystems and their water requirements (Morgan 2002). According to published accounts, this neglect has contributed to the marginalisation of Indigenous perspectives from allocation frameworks and the exclusion of Indigenous knowledge from formal management activities (see also Jackson 2009, 2011).

The Australian literature gives little attention to the economic implications of water scarcity for Indigenous people and little is known about Indigenous behavioural responses to changes in property-rights frameworks. The existence of Indigenous licence-holders (Altman and Arthur 2009) - particularly in New South Wales, where the demand for water for irrigation is high - suggests that the economic dimension is nonetheless an important one, perhaps more so in some basin subregions than others. 
Despite the diversity in water uses and values, the literature describes commonalities in perspective and attitude and consistency in the vision for the Basin articulated by Indigenous people (Jackson et al. 2010). The vision for the River Murray is 'one of a healthy, living river system with natural flows and cycles' (Morgan et al. 2004:68). During consultations in the years following the establishment of the Murray-Darling Basin Commission (MDBC), Indigenous respondents stressed the critical importance of the Basin's river systems to social, economic and cultural life and the need for balance in meeting the needs of other stakeholders. Morgan et al. (2004) argue that Indigenous people have a shared interest with the environmental community to restore ecological functions to riverine systems.

There are numerous Indigenous groups with rights and interests in the land, waters and other resources of the Basin, including the Barkindji, Nari Nari, Kamilaroi, Ngarrindjeri and Yorta Yorta. ${ }^{4}$ Across the region, Indigenous people have ownership rights to less than 0.2 per cent of the land area. A complex set of legal factors has restricted the number of Indigenous groups that have water rights recognised at law, the nature and extent of those legal rights, how much effective control any legal rights gives Indigenous rights-holders and the quantum of benefit derived from water-based enterprises on Indigenous land (Jackson 2011).

The history of water-resource development-particularly the priority of chronological possession of land and water rights - has made it difficult for Indigenous people to retain customary connection and attain legal rights to water bodies in recent native-title processes (Behrendt and Thompson 2004; McFarlane 2004). Subsequent legislative amendments have further narrowed the scope of native-title rights to water (Jackson and Altman 2009). Native-title statute and case law have established that where native title exists, there is a limited, non-exclusive and non-commercial right to use water without the need for a licence (Tan 1997). Jurisdictions appear to be waiting for native-title cases to be proven in the courts or resolved by negotiation before addressing water requirements for native title in plans, despite an NWI requirement that water plans take account of the possibility of native title (Jackson et al. 2009). ${ }^{5}$

Not surprisingly, therefore, Indigenous groups participating in the CSIRO study reported significant barriers to accessing water through allocations and thereby satisfying their water and related natural-resource management objectives. These barriers are of a legal, administrative, economic, institutional and

4 Morgan et al. (2004) estimate the presence of more than 30 Indigenous 'nations' within the Basin, each occupying core areas of land on either or both sides of each major watercourse and across catchments.

5 The CSIRO report (Jackson et al. 2010) describes the interaction of native-title law and water-resource law as well as the factors affecting Indigenous participation in basin State water planning, as do Behrendt and Thompson (2004); Jackson (2009); Rural Solutions (2008); and Tan (2009). 
epistemological nature. Notwithstanding the many impediments, Indigenous organisations are undertaking water-management activities, some are using water as a key management tool in their conservation activities, and many others want to see environmental water directed to places and features of value or significance to their local communities.

The following section outlines three socioeconomic impacts that might arise from the Basin Plan, assuming it will bring about a substantial reallocation of water to the environment.

\section{Potential Impacts from Changes to Water Availability}

A number of potential impacts resulting from changes to water availability have been identified. A full social assessment of potential changes in water availability, however, has not been undertaken and a number of caveats need to be stated: 1) the assessment carried out was constrained by a tight project time line (approximately four months); 2) there are significant gaps in knowledge of Indigenous water use, participation in the water economy and relationships to water; and 3) there are uncertainties in the nature of the change under consideration; 4) assessments of need, social vulnerability and adaptive capacity to changes in environmental policy and water availability require demographic and socioeconomic information that was not readily available; and 5) the extent of the change (SDLs) and the likely spatial distribution of impacts were not known to the researchers, limiting their ability to predict geographic areas of greatest impact with certainty. With those limitations in mind, the following potential impacts were identified.

\section{Enhanced Environmental Flows are Highly Likely to Generate Positive Impacts}

Indigenous groups have articulated a vision for restoration of a healthy MurrayDarling system, indicating that improvements to the environmental condition of the Basin will be viewed positively by many Indigenous people. The benefits accruing to Indigenous people, however, could be enhanced if reforms are made to basin State water-planning processes and environmental water governance. In the absence of changes to the way that environmental water requirements are assessed and environmental water is managed, there is a risk that the full potential for increased environmental flows to substantially benefit Indigenous people will not be realised. Ways of mitigating that risk are discussed below. 


\section{Sustainable Diversion Limits (SDLs) Might Reduce Options for Economic Development}

Indigenous people in the $\mathrm{MDB}$ use water to achieve multiple objectives, reflecting interdependencies between commercial, cultural and environmental uses, aspirations and values. Indigenous people play a small but active role in agriculture in the Basin: they own land, some have formal entitlements to water and some are employed in agriculture and related industries. The potential effect of water reductions on Indigenous settlement patterns is currently unknown (for example, intensifying the trend towards urbanisation). The disadvantaged status of Indigenous populations means that if their water entitlements are reduced sufficiently to have an impact on agricultural activity, they are likely to be particularly affected. The severity of this impact will, however, depend on the degree of Indigenous access to improved irrigation efficiency and the extent of Indigenous-owned agriculturally viable land in the areas most vulnerable to reduced water allocation.

The interdependencies between the water-based livelihood strategies employed by the Indigenous communities profiled in the CSIRO report should be taken into account. Water is both a resource that can be used as an economic asset and a feature of the cultural landscape that defines Aboriginal people's relationships to their customary lands, including their responsibilities to manage country. For example, one of the report's case studies shows that the Nari Nari people of the Murrumbidgee region use water as a management tool in the environmental and cultural restoration of their properties purchased by the Indigenous Land Corporation. Using five water licences - including a special-purpose Aboriginal Cultural Access Licence - the Nari Nari have designed a watering regime to achieve multiple non-market benefits. This group temporarily trades a highsecurity entitlement to underwrite the annual purchase of the water obtained under licence to meet their cultural and environmental objectives. This case raises many very interesting issues of equity and governance that are discussed fully in the report (Jackson et al. 2010).

Potential negative effects from changes in SDLs will need to be balanced against possible positive effects. For instance, reductions in water availability might increase the value of any high-security water entitlements held by Indigenous people or enterprises. In certain areas, the asset could also increase in value.

\section{Risks to Indigenous Engagement from Basin Planning Processes, Including Setting SDLs}

The strength of criticisms of previous water-planning and management processes reported in numerous sources suggests that the Basin planning process might have a negative effect on Indigenous people. Previously, Indigenous people 
have been critical of short planning time frames, the technical complexity of management measures such as SDLs, and the narrow ecological focus given to the definition of environmental assets or environmental water objectives. In all three cases reported in the CSIRO study, Indigenous groups have encountered considerable difficulty having their values recognised in environmental water management. Environmental water is not being directed to the features of greatest significance or value to Indigenous people interviewed for this study and for others (Weir 2009). Indigenous people interviewed during the case studies, as well as other consultations, report that they have had no opportunity to contribute to the identification of the Key Ecological Assets that will serve as a basis for the basin-wide Environmental Water Plan.

\section{Priority Actions for Indigenous Water Management}

This section outlines a set of priority actions that would improve Indigenous water management in the Basin over the next five years.

\section{Define Indigenous Water Uses and Develop Methods to Specify Indigenous Water Requirements}

One of the continuing challenges to water planning across Australia is to incorporate Indigenous issues more effectively, requiring - amongst a number of changes - that allocations are quantitatively defined in water plans (Jackson et al. 2009; National Water Commission 2008). Despite the existence of NWI guidelines for water plans to include consideration of Indigenous water use, it is rare to see a plan that specifically addresses Indigenous water requirements (Jackson 2009). The MDBA faced this challenge as it undertook its first step in developing the Basin Plan: to quantify the Basin's water resources and describe the uses to which they are put, including by Indigenous people.

Yet little is known about the current pattern of Indigenous water use in the Basin either for consumptive or for non-consumptive purposes. There are no systematic studies of water use within or across Indigenous groups, nor is there a comprehensive aggregated picture of the water requirements of the many distinct Indigenous communities where identification of critical human needs is reported to be an issue (Liz McNiven, Personal communication). There is scant detail on the Indigenous agricultural sector and its demand for water. ${ }^{6}$

6 A preliminary report on Indigenous access to commercial licences provides insight into consumptive-use rates at a coarse scale (Altman and Arthur 2009). 
Non-consumptive water requirements are also not well understood because environmental-flow assessment methods have not adequately incorporated social assessments within their methodologies (Jackson 2006, 2008). For this reason, Indigenous groups are critical of the ecological research community and State water agencies for failing to address their values in environmental water management.

As described more fully in the CSIRO study, Indigenous people place great importance on the in-stream values that sustain customary life ways, and it is this interest that has motivated some Indigenous organisations to develop their own strategies for adapting concepts such as environmental flows to meet their water requirements (Weir 2009). A major issue articulated by some Indigenous groups in the MDB is the environmental impact of over-allocation of water and the perception that the ecological criteria upon which environmental flows or in-stream values are determined are too narrow (Jackson et al. 2010; Weir 2009). The intangible values that Indigenous people regard as critical to their sense of identity, cultural practices, spiritual beliefs, customary management practices and livelihoods are consistently raised as a challenge to the quantitative and competitive methods of resource allocation currently favoured by market-based reform programs (Jackson 2006).

Some traditional owners in the MDB advocate that a specific allocation distinct from environmental flows - a cultural flow - be made on the grounds of cultural differences. The Murray Lower Darling Rivers Indigenous Nations (MLDRIN) and the Northern Basin Aboriginal Nations (NBAN) define cultural flows as water entitlements that would be owned and controlled by Indigenous groups to improve their environmental, social, cultural and economic conditions. Winning widespread support for the 'cultural flow' concept will undoubtedly be contentious given the history of Indigenous resource rights in Australia (Altman 2004), and water scarcity might raise significant implementation obstacles. A further challenge lies in developing methods to accommodate the multiple values underpinning its definition and to governing its use, allocation and the distribution of any benefits. Although some Indigenous groups have expressed an interest in conducting feasibility studies of 'cultural flows' and measuring the benefits that might ensue, the concept is highly novel and if realised would represent a 'high-water mark' in Indigenous water management. Precedence might be found in efforts to meet Maori flow preferences in New Zealand (Tipa, Personal communication). Nonetheless, the literature does not provide a clear direction on appropriate methods and approaches to advance our understanding of the implications of separate allocations to meet Indigenous customary requirements. The MDBA could take the lead in fostering such efforts with a view to providing Indigenous water-allocation mechanisms in the second iteration of the Basin Plan. 
Consideration should be given to setting benchmarks for accreditation of basin State water-resource plans that reflect Indigenous water needs. Systematic assessments of Indigenous water-use requirements might be achieved through the generation of Indigenous Water Management Plans for each catchment to achieve the objectives of the NWI. Such plans could include

- five-year targets for improved access to water

- assessments of the impact of SDLs on native-title interests

- identification of features, places and species of major significance for Indigenous people and their water requirements

- mechanisms to assist Indigenous representatives to receive, evaluate and prioritise applications for water or undertake water-related management

- monitoring and evaluation of outcomes of watering

- linkages between Indigenous representative structures, environmental groups, environmental water advisory groups, catchment management authorities (CMAs), and so on

- targets to improve Indigenous representation in water-management processes.

An Indigenous Water Fund might be established to resource these and other initiatives recommended in the full report.

\section{Increase Benefits to Indigenous People through Improved Environmental Water Management}

Traditional-owner groups express a strong desire to exercise authority, responsibility and control in the determination of allocations to meet their requirements. The benefits Indigenous people derive from increased environmental allocations could be enhanced if reforms are made to waterplanning processes and environmental water governance so that they are more inclusive of Indigenous uses, values and priorities (for example, the MDBA's Environmental Water Plan). More inclusive environmental water management would allow differences to emerge in the priority given to the selection of environmental outcomes (for example, aquatic species of totemic significance, wetlands of value for customary use). Environmental water programs (for example, buybacks) need to be more accessible to Indigenous people and the opportunities for co-management with Indigenous natural-resource management (NRM) groups investigated, particularly in relation to Indigenous conservation activities (for example, joint management, Indigenous Protected Areas). To do so might require amendments to the Water Act given the narrowness of the definition of environmental outcomes to be achieved through the delivery of environmental water (that is, ecosystem function, biodiversity, water quality). 
In exploring the feasibility of Indigenous-specific flows, the governance issues associated with a range of entitlement-holding and management models will need further investigation. Assistance will be needed to develop governance arrangements to support Indigenous management of water allocations. Investing in Indigenous capacity to contribute knowledge and manage environmental water offers one means of enhancing the potential benefits from greater access to water under the Basin Plan. This capacity could also spill over into other areas of natural-resource management (for example, national parks and Indigenous Protected Areas), and bring broader social and economic benefits (Hunt et al. 2009). Capacity should be built at, at least, two scales: the catchment level, where Indigenous groups need assistance to articulate their priorities and bring their knowledge to water assessment, administration and management processes; and at the regional scale, where northern and southern Indigenous alliances ${ }^{7}$ need assistance to analyse data, reflect on trends in water access and participation in management, contribute to research on ways of quantifying Indigenous water requirements and to offer policy advice on overcoming barriers to Indigenous access to water, as well as Basin Plan implementation and adaptation. Close links between the two scales will improve the relevance of Indigenous policy contributions to local community needs and provide legitimacy for region-wide Indigenous contributions to Commonwealth water-management instruments such as the Environmental Water Plan.

\section{Improve Indigenous Livelihood Outcomes from SDLs}

Although Indigenous people are statistically under-represented in the allocation of water for commercial purposes, our understanding of Indigenous rates of participation in the water economy and degrees of water dependence is poor. Altman and Arthur (2009:9) conclude that in the absence of 'good knowledge of present or future water allocation and use, it is difficult to see how Indigenous users can be properly incorporated into planning or allocation processes'. Indigenous commercial water users need to be identified in order to determine whether SDLs will adversely affect the commercial viability of their enterprises. In such instances, Indigenous people should be made aware of any structuraladjustment programs developed by or in response to the Basin Plan. There is also considerable potential for structural change to present new opportunities for Indigenous people in emerging cultural and natural resource-based industries, such as payment for environmental services, stewardship arrangements, smallscale bush-foods businesses, and tourism.

7 The MLDRIN and the NBAN. 


\section{Improve the Knowledge Base for the Next Plan}

A strong evidence base is needed to provide for a continual process of adaptive learning; information is needed to evaluate potential impacts prior to Basin Plan implementation and to develop adaptation responses, to monitor Plan implementation, and, in turn, to integrate revised needs into the next plan. The lack of quantitative data on Indigenous water use and sensitivity to change constrains water planning and, in particular, the ability to measure the impacts of SDLs. Effective mitigation strategies require monitoring to evaluate the impacts of the Basin Plan on Indigenous enterprises and communities during the life of the Plan.

Baseline socioeconomic and demographic data should be collected and a monitoring program designed to track changes in SDLs and impacts on Indigenous access to water and economic participation. To effectively and equitably manage water resources in the MDB there needs to be further research across a range of areas, including

1. baseline information - for example, on Indigenous commercial water use, socioeconomic regional profiles, and so on, which will also facilitate monitoring

2. understanding of the barriers to Indigenous participation in the water market

3. understanding of the 'cultural flows' concept articulated by Indigenous groups and how it aligns with environmental flows including under differing management models; a series of in-depth case studies that identifies Indigenous water requirements in all basin jurisdictions would advance this knowledge gap

4. techniques to quantify Indigenous environmental and cultural water use and evaluate benefits

5. water policy instruments to better accommodate Indigenous people's cultural, environmental and economic needs.

\section{Conclusion}

The Basin Plan and government responses to implementation and mitigation present a significant opportunity to address the longstanding neglect of Indigenous interests in water management and planning, as well as to markedly improve the extent to which Indigenous people benefit from water reforms, particularly from environmental water management. As water policy makers and planners seek to address the requirements of the Water Act and the NWI, they confront substantial gaps in our knowledge of Indigenous requirements 
for water and governance models to improve Indigenous water management. Research and dialogue are needed to further the conceptual and empirical understanding of Indigenous water requirements, values and governance, and, in doing so, to fully involve Indigenous people in subsequent policy development and decision making. In the short term, action is required from basin States to improve Indigenous access to water under water-resource plans and to adapt environmental water-management systems to better address Indigenous world views and relationships to country if the imperatives of the NWI are to be met. The effect of changes in water availability for Indigenous commercial uses - and any knock-on effects on non-consumptive uses - still requires better understanding and should be carefully monitored prior to and during Basin Plan implementation.

\section{References}

Altman, J. 2004, 'Economic development and Indigenous Australia: contestation over property, institutions and ideology', Australian Journal of Agricultural and Resource Economics, vol. 48, pp. 513-34.

Altman, J. and Arthur, B. 2009, Water Licences and Allocations to Indigenous People for Commercial Purposes: An Australia-wide scoping exercise, ANU Centre for Aboriginal Economic Policy Research, Canberra.

Behrendt, J. and Thompson, P. 2004, 'The recognition and protection of Aboriginal interests in New South Wales rivers', Journal of Indigenous Policy, vol. 3, pp. 37-140.

Forward NRM and Arrilla-Aboriginal Training and Development 2003, Scoping Study for Indigenous Involvement in Natural Resource Management DecisionMaking and the Integration of Indigenous Cultural Heritage Considerations into Relevant Murray-Darling Basin Commission Programs, Murray-Darling Basin Commission, Canberra.

Hunt, J., Altman, J. and May, K. 2009, Social benefits of Aboriginal engagement in natural resource management, CAEPR Working Paper No. 60, ANU Centre for Aboriginal Economic Policy Research, Canberra.

Jackson, S. 2006, 'Compartmentalising culture: the articulation and consideration of Indigenous values in water resource management', Australian Geographer, vol. 37, no. 1, pp. 19-31. 
Jackson, S. 2008, 'Recognition of Indigenous interests in Australian water resource management, with particular reference to environmental flow assessment', Geography Compass (Environment \& Society), vol. 2, no. 3, pp. 874-98.

Jackson, S. 2009, National Indigenous water planning forum: background paper on Indigenous participation in water planning and access to water, Unpublished report prepared for the National Water Commission, CSIRO, Darwin.

Jackson, S., P. Tan, and Altman J. 2009. Indigenous Fresh Water Planning Forum: Proceedings, Outcomes and Recommendations. A Report to the National Water Commission, Canberra, http:/www.nwc.gov.au/resources/ documents/Outcomes_of_NWC_Indigenous_Fresh_Water_Planning_ Forum_outcomes2.pdf>

Jackson, S. 2011, 'Aboriginal access to water in Australia: opportunities and constraints', in Q. Grafton and K. Hussey (eds), Water Resources, Planning and Management, Cambridge University Press, UK, pp. 601-28.

Jackson, S. and Altman, J. 2009, 'Indigenous rights and water policy: perspectives from tropical north Australia', Australian Indigenous Law Review, vol. 13, no. 1, pp. $27-48$.

Jackson, S., Moggridge, B. and Robinson, C. 2010, The Effects of Change in Water Availability on Indigenous People of the Murray Darling Basin: A scoping study, Murray-Darling Basin Authority, Canberra, <www.mdba.gov.au>

McFarlane, B. 2004, The National Water Initiative and acknowledging Indigenous interests in planning, Paper presented to the National Water Conference, Sydney, 29 November 2004.

Morgan, M. 2002, MLDRIN Response to the Draft Water Sharing Plan for the NSW Murray Lower Darling Regulated River Water Source, Prepared by the Murray Lower Darling Community Reference Committee.

Morgan, M., Strelein, L. and Weir, J. 2004, Indigenous Rights to Water in the Murray Darling Basin, Australian Institute of Aboriginal and Torres Strait Islander Studies, Canberra.

National Water Commission 2008, Update of Progress in Water Reform: Input into the water sub group stocktake report, National Water Commission, Canberra.

Rural Solutions 2008, Aboriginal Access to Water Across Australia, Department of Water, Land and Biodiversity Conservation, Government of South Australia, Adelaide. 
Tan, P. 1997, 'Native title and freshwater resources', in B. Horrigan and S. Young (eds), Commercial Implications of Native Title, The Federation Press, Sydney, pp. 157-90.

Tan, P. 2009, National Indigenous Water Planning Forum: A review of the legal basis for Indigenous access to water, An unpublished report prepared for the National Water Commission, Canberra.

Taylor, J. and Biddle, N. 2004, Indigenous people in the Murray-Darling Basin: a statistical profile, Discussion Paper 264, ANU Centre for Aboriginal Economic Policy Research, Canberra.

United Nations 2008, Declaration on the Rights of Indigenous Peoples, United Nations, New York.

Ward, N. 2009, 'Good methodology travels: Australian case study', in T. Tobias (ed.), Living Proof: The essential data-collection guide for Indigenous use-andoccupancy map surveys, Ecotrust Canada and Union of British Columbia Indian Chiefs, Vancouver, pp. 339-64.

Weir, J. 2009, Murray River Country: An ecological dialogue with traditional owners, Aboriginal Studies Press, Canberra. 